\title{
Fluvial organic carbon losses from a Bornean blackwater river
}

\author{
S. Moore ${ }^{1}$, V. Gauci ${ }^{1}$, C. D. Evans ${ }^{2}$, and S. E. Page ${ }^{3}$ \\ ${ }^{1}$ CEPSAR, Dept. of Earth and Environmental Sciences, The Open University, Walton Hall, Milton Keynes, MK7 6AA, UK \\ ${ }^{2}$ Centre for Ecology and Hydrology, Environment Centre Wales, Deiniol Road, Bangor, LL57 2UW, UK \\ ${ }^{3}$ Department of Geography, University of Leicester, University Road, Leicester, LE1 7RH, UK
}

Received: 5 November 2010 - Published in Biogeosciences Discuss.: 12 November 2010

Revised: 14 February 2011 - Accepted: 29 March 2011 - Published: 13 April 2011

\begin{abstract}
Concentrations of dissolved organic carbon (DOC) and particulate organic carbon (POC) were analysed from the source to the mouth of the River Sebangau in Central Kalimantan, Indonesia during the dry and wet seasons in 2008/2009 and an annual total organic carbon (TOC) flux estimated. DOC concentrations were higher and POC concentrations lower in the wet season compared to the dry season. As seen in other tropical blackwater rivers, DOC concentration is consistently around 10 times greater than POC concentration. We estimate the annual TOC flux discharged to the Java Sea to be $0.46 \mathrm{Tg}_{\text {year }}{ }^{-1}$ comprising of $93 \%(0.43 \mathrm{Tg}) \mathrm{DOC}$ and $7 \%(0.03 \mathrm{Tg}) \mathrm{POC}$. This equates to a fluvial TOC loss flux per unit area over the entire Sebangau catchment of $88 \mathrm{~g} \mathrm{C} \mathrm{m}^{-2} \mathrm{yr}^{-1}$. When extrapolating the River Sebangau DOC loss flux $\left(83 \mathrm{~g} \mathrm{C} \mathrm{m}^{-2} \mathrm{yr}^{-1}\right)$ to the peat covered area of Indonesia $\left(206950 \mathrm{~km}^{2}\right)$, we estimate a DOC loss of $17.2 \mathrm{TgC} \mathrm{yr}^{-1}$ or $\sim 10 \%$ of current estimates of the global annual riverine DOC discharge into the ocean.
\end{abstract}

\section{Introduction}

The transport of carbon from terrestrial ecosystems such as peatlands into rivers and out to the oceans plays an important role in the carbon cycle because it provides a link between the terrestrial and marine carbon cycles (Meybeck, 1993). It is not yet known how much of the fluvial organic carbon that is lost from peatlands is converted into carbon dioxide and/or methane and lost to the atmosphere, nor do we fully understand the quantity of carbon that remains climatically neutral through benthic deposition and storage as riverine and estuarine sediments (Battin et al., 2009). In terms of a global riverine flux of carbon, it is estimated that 1000 teragrams

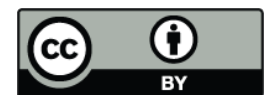

Correspondence to: S. Moore (s.moore@open.ac.uk)
( Tg) $\left(1 \mathrm{Tg}=10^{12}\right.$ grams $\left.(\mathrm{g})\right)$ of carbon is discharged into the world's oceans each year (Ludwig et al., 1996). Of this carbon, approximately $60 \%$ is comprised of inorganic carbon and 40\% is organic carbon (Meybeck 1993; Probst et al., 1994). For most rivers a greater proportion of carbon is lost to the oceans in inorganic forms (Meybeck, 1982), however, it is believed that in tropical peat swamp forest (PSF) catchments, fluvial carbon fluxes to the oceans are dominated by organic forms. Two commonly accepted estimates put the annual figure of total organic carbon (TOC) discharged to oceans as somewhere between 330 and $370 \mathrm{Tg}$ (Degens et al., 1991; Meybeck, 1993).

Riverine TOC is made up of two components; dissolved organic carbon (DOC) and particulate organic carbon (POC). The distinction between these two components is generally made on the basis of whether or not material passes through a $0.45 \mu \mathrm{m}$ filter; i.e. DOC will pass through as filtrate and POC will be retained by a filter of this pore size (Thurman, 1985). Additional subdivisions can be made within these two components as they are made up of a continuous spectrum of different sized molecules. Fulvic and humic acids comprise about $50-75 \%$ of DOC and colloidal organic matter is the other main constituent comprising around 20\% (Hope et al., 1994). Humic acids are responsible for the dark colour of blackwater rivers. POC consists mainly of plant litter and soil organic matter and can also be subdivided according to size; coarse $(>1 \mathrm{~mm})$, fine $(1 \mathrm{~mm}-53 \mu \mathrm{m})$, and very fine $(53 \mu \mathrm{m}-$ $0.45 \mu \mathrm{m})$ (Naiman et al., 1987).

Globally, POC fluxes comprise approximately $10 \%$ of TOC fluxes, although for individual rivers the POC/DOC ratio is subject to large variation being dependent upon a number of variables such as catchment ecosystem type, river size and velocity. In most peatland ecosystems nearly $100 \%$ of TOC is exported as DOC (Hope et al. 1994). According to various modelling estimates, the global river-toocean DOC flux ranges from 170 (Harrison et al., 2005) to $250 \mathrm{Tg} \mathrm{C} \mathrm{yr}^{-1}$ (Ludwig et al., 1996). Indonesian rivers

Published by Copernicus Publications on behalf of the European Geosciences Union. 
account for approximately $11 \%\left(4.26 \times 10^{12} \mathrm{~m}^{3} \mathrm{yr}^{-1}\right)$ of global freshwater discharge into the oceans (Syvitski et al., 2005) and are considered to be large contributors of DOC. This is primarily due to high precipitation rates and large surface areas that are covered in peatlands $\left(206950 \mathrm{~km}^{2}\right)$ (Page et al., 2010), which are known to be an important source of riverine DOC (Hope et al., 1997; Aitkenhead and McDowell 2000). In a recent study, Baum et al. (2007) used data collected from the River Siak, a blackwater river in Sumatra

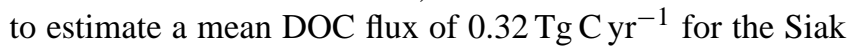
catchment alone. This estimate was then extrapolated to the entire land area of Indonesia $\left(\sim 1.9 \times 10^{6} \mathrm{~km}^{2}\right)$, taking into account the percentage peat area cover, and the annual fluvial DOC discharge was estimated to be $21 \mathrm{Tg} \mathrm{yr}^{-1}$. According to the extrapolated estimate of Baum et al. (2007) and the current global modelling estimates (170-250 $\mathrm{Tg} \mathrm{yr}^{-1}$ ), Indonesian rivers account for approximately $10 \%$ of the global riverine DOC discharge into the ocean.

The value of this extrapolated estimate is, however, reduced by the limited availability of fluvial carbon data for other rivers in the region. Here we seek to remedy this deficiency by reporting data from an additional Indonesian blackwater river, the River Sebangau, in Central Kalimantan. Our study aims to quantify the export of organic carbon in this river from the source $(150 \mathrm{~km}$ inland $)$ to the mouth where it discharges into the Java Sea.

\section{Methods}

\subsection{Study site}

The Sebangau River catchment lies in the southern part of Central Kalimantan, Indonesia. Central Kalimantan lies within the inter-tropical convergence zone (ITCZ) and experiences a tropical-monsoonal climate. The temperature remains relatively constant throughout the year $\left(25-27^{\circ} \mathrm{C}\right)$ and annual rainfall averages $2700 \mathrm{~mm} \mathrm{yr}^{-1}$ (Page et al., 2004). Twenty-four years of rainfall records from Central Kalimantan indicate that annually there is approximately 9 months of wet season (October-June) and 3 months of dry season (July-September; dry months defined as periods of moisture deficit, i.e. when evapotranspiration exceeds rainfall) (Hooijer et al., 2008) (Fig. 1). The Sebangau catchment lies between the River Katingan to the west and the River Kahayan to the east and has a total land area of approximately $5200 \mathrm{~km}^{2}$ (Fig. 2). Kya, the source of the River Sebangau is approximately $20 \mathrm{~km}$ west of Palangka Raya, the provincial capital of Central Kalimantan. Almost the entire catchment is composed of peatland resulting in a high concentration of humic substances in the water, giving the River Sebangau water it's characteristically dark orange-black colour and a background $\mathrm{pH}$ of 3.5-4.0 (Haraguchi 2007). The maximum tidal range at the mouth of the River Sebangau is $\sim 3 \mathrm{~m}$ (UKHO, 2008). Due to the low-lying nature of the Sebangau

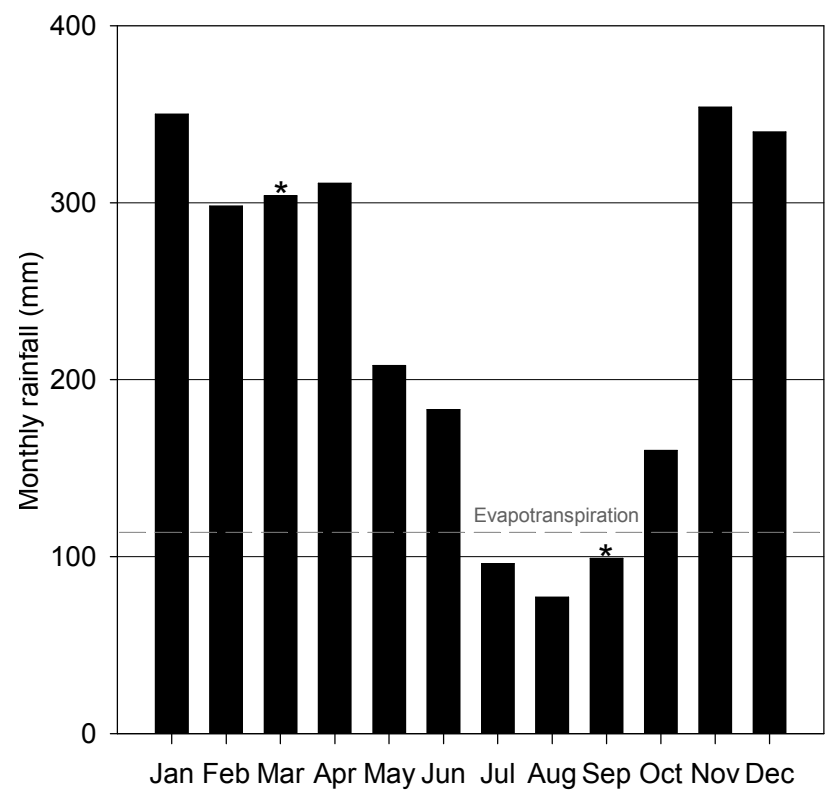

Fig. 1. Average monthly rainfall over 24-year record (1984-2006) in Central Kalimantan. Data presented is the lower 50-percentile of the driest years $(1983,1990,1991,1994,1996,1997,1999,2000$, 2001, 2002, 2004, 2006). Dashed line represents the average evapotranspiration over the same time period. All data collected from Palangka Raya Meteorological Office (Hooijer et al., 2008).

* Denotes timing of the two sampling campaigns.

catchment this mesotidal range has the potential to affect the river system over large distances inland.

\subsection{Sample collection}

Sampling was carried out on two separate occasions; the dry season in September 2008 (high-tide) and the subsequent wet season in March 2009 (low-tide). River water samples were collected from the main channel of the Sebangau at $3 \mathrm{~km}$ intervals from the mouth to the source, $150 \mathrm{~km}$ inland (a total of 50 samples). Baum et al. (2007) reported horizontal and vertical DOC variability in a blackwater river in Sumatra to be $\pm 5 \%$ and $\pm 3 \%$ respectively, due to well mixed water. Accordingly, all samples were collected from the centre of the River Sebangau at a depth of $50 \mathrm{~cm}$. Five replicate samples were collected from within each of the fourteen channels at a point immediately before their discharge points into the River Sebangau. The cross-sectional area (CSA) and five replicate flow rate measurements (FR) (converted from impeller counts (C) per minute using the formula: $\mathrm{FR}=0.000854 \mathrm{C}+0.05)$ using a handheld impeller flow meter were also taken and used to calculate the discharge $(Q)$ from each of the fourteen channels, as well as at the mouth of the River Sebangau upon discharging into the Java Sea, using the formula: $Q\left(\mathrm{~m}^{3} \mathrm{~s}^{-1}\right)=\mathrm{FR}\left(\mathrm{m} \mathrm{s}^{-1}\right) \times \mathrm{CSA}\left(\mathrm{m}^{2}\right)$. Precision for this 


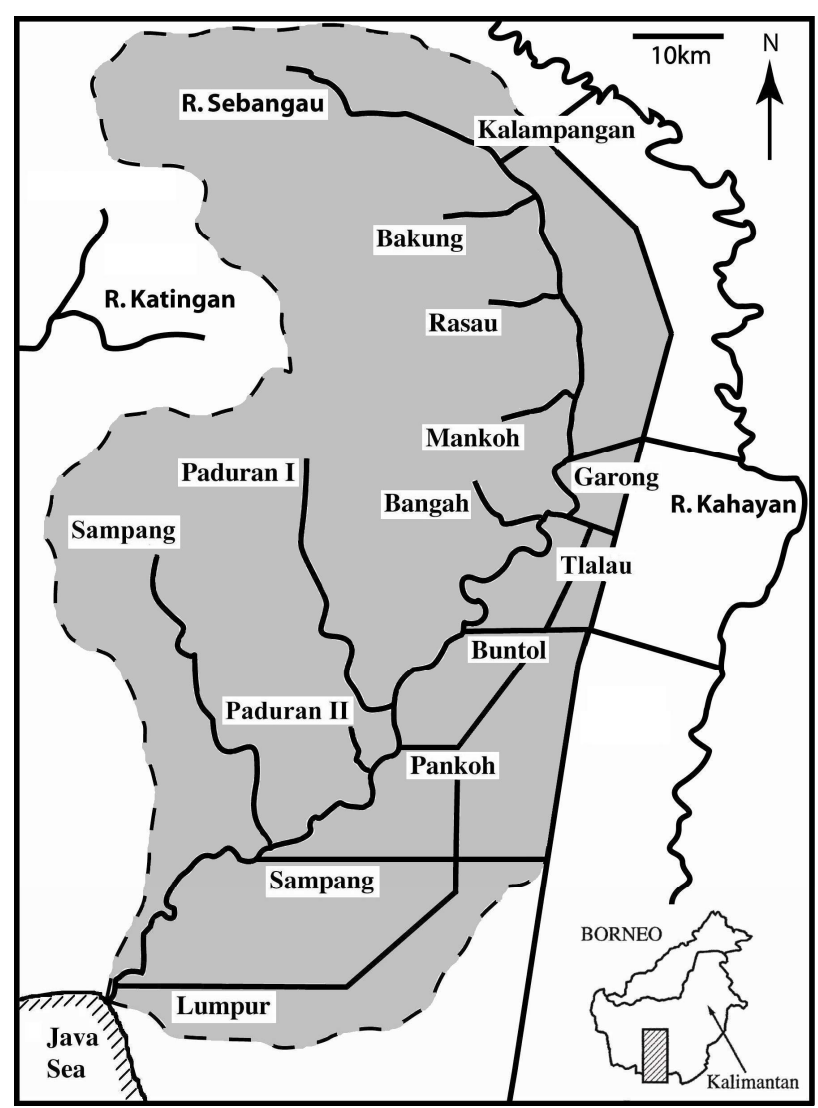

Fig. 2. Map of the Sebangau River basin in Central Kalimantan, Borneo (inset). The Sebangau watershed is shaded grey and outlined by the dashed line to the west and the straight solid line (northsouth canal) to the east. Fourteen named channels drain the Sebangau catchment into the River Sebangau (centre) which runs from North to South draining into the Java Sea. To the west of the northern stretches of the Sebangau River lies the Sebangau National Park which contains intact PSF (Page et al., 1999). To the west of the southern stretches of the Sebangau is a transmigration settlement area which experienced deforestation and land-use change in the 1970s through to the 1990s. The east side of the Sebangau basin is "Block C" of the Ex-Mega Rice Project (EMRP). The EMRP, which began in 1995, converted peatland into land suitable for agriculture by clearing the land and creating drainage canals to artificially control water table levels (Hooijer et al., 2008). A combination of peatland drainage and fires has created a much changed and degraded ecosystem (Page et al., 2002; Wösten and Ritzema, 2007; Ballhorn et al., 2009; Page et al., 2009).

method was better than $\pm 5 \%$. Samples were collected in pre-rinsed $60 \mathrm{ml}$ Nalgene bottles and the position of each sample point was recorded using a GPS (Garmin, eTrex Venture). Water temperature, $\mathrm{pH}$ and electrical conductivity (EC) were recorded immediately after collection using portable pH (Hanna HI9024D) and EC (Hanna HI8633) meters.

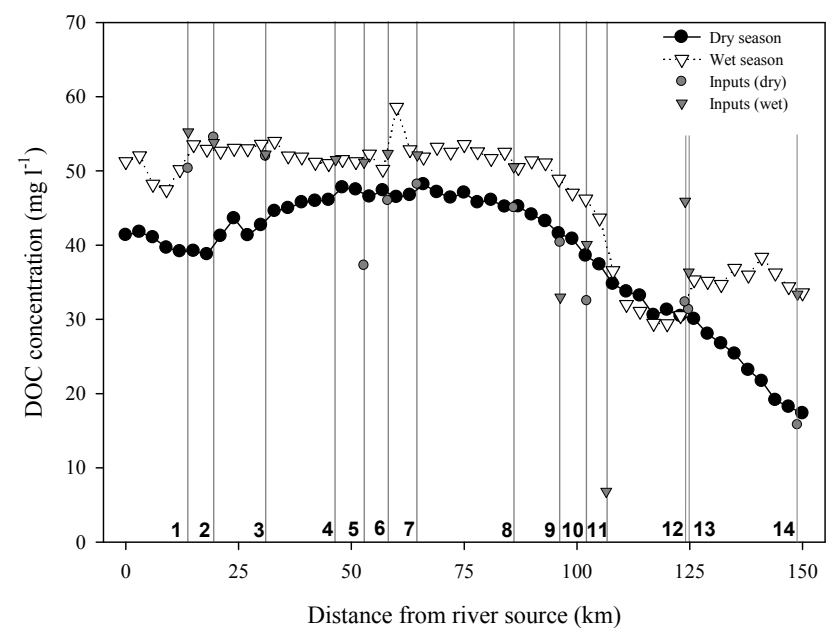

Fig. 3. DOC concentration along the course of the River Sebangau during the dry and wet seasons. Vertical lines represent the confluences of fourteen channels that discharge into the River Sebangau. Each confluence has an identification number above the $\mathrm{x}$-axis (see Table 1). Single point data represent DOC concentrations in each channel prior to discharge into the River Sebangau.

\subsection{Sample preparation and analysis}

To derive POC concentration, a known volume of river water was filtered through a $0.45 \mu \mathrm{m}$ cellulose acetate membrane filter that had been pre-rinsed with excess sample (Whatman) under partial vacuum (hand-held vacuum pump, Mityvac, Nalgene). The filter was retained and oven dried $(24 \mathrm{~h}$ at $40^{\circ} \mathrm{C}$ ) to quantify particulate matter which is thought to be equal to particulate organic matter (POM) (given the dominance of peat soil in the catchment). POM was then converted to a POC value by assuming organic matter to be $50 \%$ carbon (Hope et al., 1994). Samples of filtrate were acidified to $\mathrm{pH} 2.0$ using a solution of dilute sulphuric acid (20\%). The samples were then stored at $2-5^{\circ} \mathrm{C}$ and analysed for DOC after the samples were returned to the Open University. DOC was measured by high-temperature catalytic oxidation $\left(680^{\circ} \mathrm{C}\right)$ using a Total Organic Carboniser (Shimadzu, TOC- $\left.\mathrm{V}_{\mathrm{CPN}}\right)$ complete with a platinum catalyst. Precision was better than $\pm 1 \%$. DOC/POC concentrations were then combined with discharge rates to calculate the TOC flux from each of the fourteen channels and the River Sebangau TOC flux to the Java Sea.

\section{Results}

\subsection{DOC}

DOC comprised $88 \%$ and $94 \%$ of TOC in the dry and wet seasons, respectively. DOC concentrations within the River Sebangau fluctuate from source to mouth and in both seasons were lower at the river mouth than at the source (Fig. 3). 

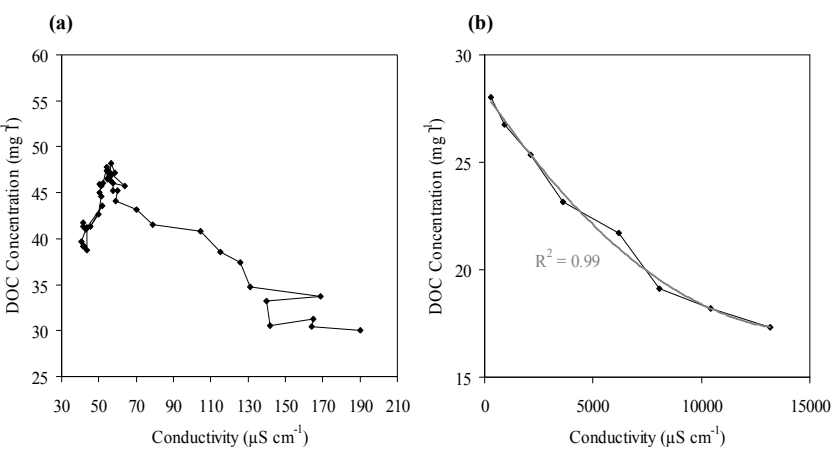

(c)

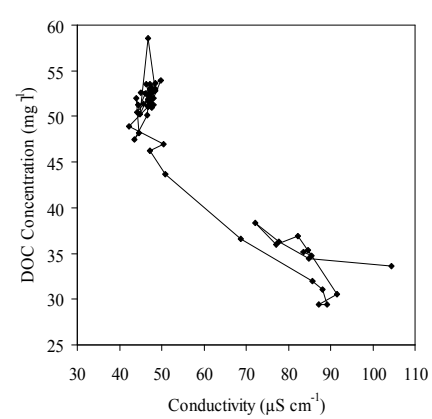

Fig. 4. Temperature corrected EC (as a proxy for salinity) vs DOC concentration plots for samples from the River Sebangau in the dry season (a) 0-126 km from source and (b) $126-150 \mathrm{~km}$ from source (polynomial 2nd order relationship; $r^{2}=0.99$ ) and the wet season (c) $0-150 \mathrm{~km}$ from source. Note different y axis scale in Fig. $4 \mathrm{~b}$.

DOC concentration remained relatively constant for the first $100 \mathrm{~km}$ from the source but then decreased as water entered the last $50 \mathrm{~km}$ of the river before discharging into the Java Sea. In the wet season, concentrations averaged $52 \mathrm{mg}^{-1}$ for the first $100 \mathrm{~km}$ of the river and $44 \mathrm{mgl}^{-1}$ during the dry season over the same stretch. Concentrations of DOC decreased beyond this point to an average of $28 \mathrm{mg} \mathrm{l}^{-1}$ and $35 \mathrm{mgl}^{-1}$ in the last $50 \mathrm{~km}$ of the river in the dry and wet seasons, respectively.

Differences between the two sampling runs are partly attributable to differences in tidal conditions; dry season sampling was undertaken at high tide, and some influence of sea-water (defined as electrical conductivity (EC) $>200 \mu \mathrm{S} \mathrm{cm}^{-1}$ ) was observed in samples collected below $126 \mathrm{~km}$ from the source. Dry season samples above and below this point were therefore analysed separately. In the wet season, sampling was undertaken at low tide, and all samples had conductivity $<110 \mu \mathrm{Scm}^{-1}$, implying that all samples contained freshwater. All wet season samples were therefore analysed together. Figures 4a, c show that from 0-126 km from the source, the river follows a similar transition in both seasons; from stable (high DOC, low EC) peat-derived water $(0-90 \mathrm{~km})$ through to a more peat/mineral-derived mix of water with a higher EC and lower DOC concentration further downstream. In the dry season, below $126 \mathrm{~km}$ from

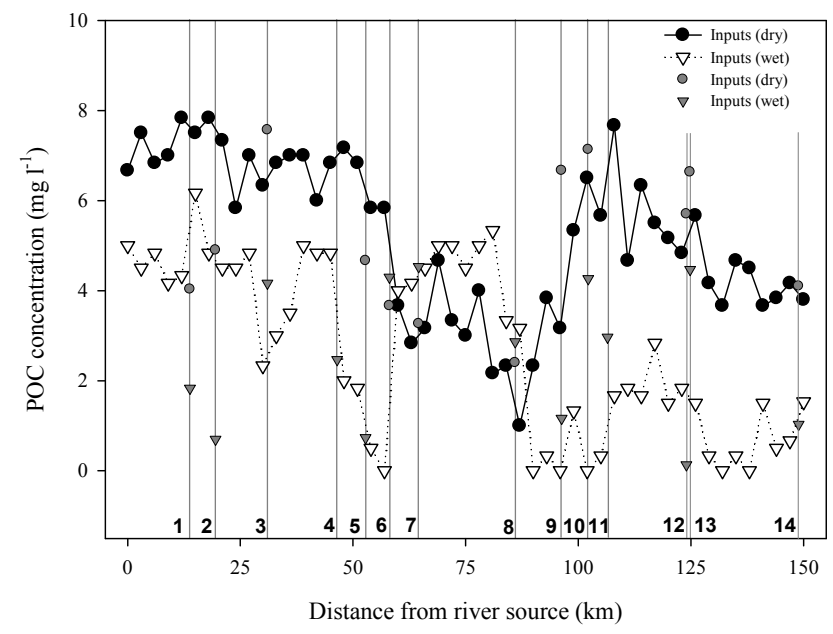

Fig. 5. POC concentration along the course of the River Sebangau during the dry and wet seasons. Vertical lines represent the confluences of fourteen channels that discharge into the River Sebangau. Each confluence has an identification number above the $\mathrm{x}$-axis (see Table 1). Single point data represent POC concentrations in each channel prior to discharge into the River Sebangau.

the source, the river water becomes progressively mixed with seawater, raising the EC and lowering DOC concentrations. The EC vs DOC relationship 126-150 km from source (Fig. 4b) is not linear, and therefore cannot be explained by conservative mixing (see discussion).

\subsection{POC}

POC comprised $12 \%$ and $6 \%$ of TOC in the dry and wet seasons, respectively. Figure 5 shows that despite varying concentrations and high spatial variability, POC followed a similar trend in both the dry and wet seasons; a decrease in concentration from source to mouth. The increase (wet season) and decrease (dry season) in POC concentration between $50-100 \mathrm{~km}$ from the source is perhaps attributable to the input of larger and smaller POC fluxes from channels 6 and 7 in the wet and dry seasons respectively (Table 1); channel 6 (Tlalau) discharged $100 \mathrm{~kg} \mathrm{day}^{-1}$ in the dry season compared to $1400 \mathrm{~kg} \mathrm{day}^{-1}$ in the wet season. Similarly channel 7 (Bangah) discharged $1800 \mathrm{~kg} \mathrm{day}^{-1}$ compared to $6300 \mathrm{~kg} \mathrm{day}^{-1}$ in the dry and wet seasons respectively. Across both seasons, average POC concentrations $0-25 \mathrm{~km}$ from the source were $\sim 4$ times higher than POC concentrations $125-150 \mathrm{~km}$ from the source. This difference is most pronounced in the wet season when the average POC concentration is $\sim 7$ times greater $0-25 \mathrm{~km}$ from the source $\left(4.8 \mathrm{mg}^{-1}\right)$ than at $125-150 \mathrm{~km}$ from the source $\left(0.7 \mathrm{mg} \mathrm{l}^{-1}\right)$. 
Table 1. Mean discharge, DOC, POC and TOC concentrations $( \pm$ s.e.) and fluxes (s.e. $<1 \%)$ from the confluences of 14 channels that discharge into the River Sebangau, during the dry and the wet season in 2008/09. The row titled River Sebangau represents concentrations and fluxes from the River Sebangau to the Java Sea. Total mean includes the 14 channels, but not the River Sebangau data.

\begin{tabular}{|c|c|c|c|c|c|c|c|c|c|c|c|c|c|c|c|c|}
\hline \multirow{2}{*}{$\begin{array}{l}\text { Number } \\
\text { on } \\
\text { graph }\end{array}$} & \multirow[t]{2}{*}{ Channel } & \multirow{2}{*}{$\begin{array}{l}\text { Distance from } \\
\text { river source } \\
(\mathrm{km})\end{array}$} & \multicolumn{2}{|c|}{$\begin{array}{l}\text { Discharge } \\
\left(\mathrm{m}^{3} \mathrm{~s}^{-1}\right)\end{array}$} & \multicolumn{2}{|c|}{$\begin{array}{l}\text { DOC concentration } \\
\left(\mathrm{mgl}^{-1}\right)\end{array}$} & \multicolumn{2}{|c|}{$\begin{array}{c}\text { DOC flux } \\
\left(\times 10^{3} \mathrm{~kg} \mathrm{day}^{-1}\right)\end{array}$} & \multicolumn{2}{|c|}{$\begin{array}{l}\text { POC Concentration } \\
\left(\mathrm{mgl}^{-1}\right)\end{array}$} & \multicolumn{2}{|c|}{$\begin{array}{c}\text { POC flux } \\
\left(\times 10^{3} \mathrm{~kg} \mathrm{day}^{-1}\right)\end{array}$} & \multicolumn{2}{|c|}{$\begin{array}{l}\text { TOC Concentration } \\
\left(\mathrm{mg} \mathrm{l}^{-1}\right)\end{array}$} & \multicolumn{2}{|c|}{$\begin{array}{c}\text { TOC flux } \\
\left(\times 10^{3} \mathrm{~kg} \mathrm{day}^{-1}\right)\end{array}$} \\
\hline & & & Dry & Wet & Dry & Wet & Dry & Wet & Dry & Wet & Dry & Wet & Dry & Wet & Dry & Wet \\
\hline 1 & Kalampangan & 13.8 & 0.2 & 1.1 & $50.3 \pm 0.3$ & $55.3 \pm 0.2$ & 0.1 & 5.3 & $4.0 \pm 0.2$ & $1.8 \pm 0.1$ & 0.1 & 0.2 & $54.4 \pm 0.5$ & $57.1 \pm 0.3$ & 1.0 & 5.4 \\
\hline 2 & Bakung & 19.5 & 2.7 & 5.5 & $54.5 \pm 0.2$ & $53.8 \pm 0.3$ & 12.6 & 25.6 & $4.9 \pm 0.1$ & $0.7 \pm 0.1$ & 1.1 & 0.3 & $59.4 \pm 0.3$ & $54.5 \pm 0.3$ & 13.8 & 25.9 \\
\hline 3 & Rasau & 31.0 & 4.4 & 9.0 & $52.0 \pm 0.1$ & $52.3 \pm 0.2$ & 19.8 & 40.8 & $7.6 \pm 0.2$ & $4.2 \pm 0.4$ & 2.9 & 3.3 & $59.6 \pm 0.3$ & $56.4 \pm 0.6$ & 22.7 & 44.1 \\
\hline 4 & Mangkoh & 46.5 & dna & 7.9 & dna & $51.5 \pm 0.2$ & dna & 35.2 & dna & $2.5 \pm 0.5$ & dna & 1.7 & dna & $54.0 \pm 0.7$ & dna & 36.9 \\
\hline 5 & Garong & 52.8 & 0.7 & 5.4 & $37.3 \pm 0.3$ & $51.2 \pm 0.1$ & 2.4 & 23.9 & $4.7 \pm 0.3$ & $0.7 \pm 0.1$ & 0.3 & 0.3 & $41.9 \pm 0.6$ & $51.9 \pm 0.2$ & 2.7 & 24.2 \\
\hline 6 & Tlalau & 58.1 & 0.2 & 3.7 & $46.0 \pm 0.3$ & $52.3 \pm 0.4$ & 0.8 & 16.9 & $3.7 \pm 0.2$ & $4.3 \pm 0.2$ & 0.1 & 1.4 & $49.6 \pm 0.5$ & $56.6 \pm 0.6$ & 0.8 & 18.3 \\
\hline 7 & Bangah & 64.6 & 6.3 & 16.1 & $48.2 \pm 0.3$ & $52.1 \pm 0.1$ & 26.3 & 72.5 & $3.3 \pm 0.4$ & $4.5 \pm 0.3$ & 1.8 & 6.3 & $51.4 \pm 0.7$ & $56.7 \pm 0.4$ & 28.0 & 78.8 \\
\hline 8 & Buntol & 86.0 & 2.9 & 11.3 & $45.0 \pm 0.5$ & $50.6 \pm 0.2$ & 11.1 & 49.5 & $2.4 \pm 0.2$ & $2.9 \pm 0.2$ & 0.6 & 2.8 & $47.4 \pm 0.7$ & $53.4 \pm 0.4$ & 11.7 & 52.4 \\
\hline 9 & Paduran I & 96.3 & 59.4 & 235.0 & $40.4 \pm 0.8$ & $33.0 \pm 0.3$ & 207.2 & 669.9 & $6.7 \pm 0.2$ & $1.2 \pm 0.1$ & 34.2 & 23.7 & $47.0 \pm 1.0$ & $34.2 \pm 0.4$ & 241.4 & 693.6 \\
\hline 10 & Pankoh & 102.2 & 8.8 & 10.6 & $32.5 \pm 0.4$ & $40.1 \pm 0.4$ & 24.8 & 36.8 & $7.1 \pm 0.2$ & $4.3 \pm 0.1$ & 5.4 & 3.9 & $39.6 \pm 0.6$ & $44.4 \pm 0.5$ & 30.2 & 40.7 \\
\hline 11 & Paduran II & 106.5 & dna & 40.7 & dna & $6.8 \pm 0.1$ & dna & 24.0 & dna & $3.0 \pm 0.2$ & dna & 10.4 & dna & $9.8 \pm 0.3$ & dna & 34.4 \\
\hline 12 & Sampang & 124.0 & 52.8 & 59.1 & $32.3 \pm 0.3$ & $45.9 \pm 0.3$ & 147.5 & 234.4 & $5.7 \pm 0.2$ & $0.1 \pm 0.1$ & 26.0 & 0.7 & $38.0 \pm 0.5$ & $46.0 \pm 0.4$ & 173.5 & 235.1 \\
\hline 13 & Sampang & 124.8 & 25.0 & 29.8 & $31.3 \pm 0.2$ & $36.4 \pm 0.4$ & 67.6 & 93.6 & $6.6 \pm 0.1$ & $4.5 \pm 0.2$ & 14.3 & 11.5 & $37.9 \pm 0.3$ & $40.8 \pm 0.6$ & 81.9 & 105.1 \\
\hline \multirow[t]{3}{*}{14} & Lumpur & 148.9 & 43.6 & 38.6 & $15.8 \pm 0.1$ & $33.4 \pm 0.1$ & 59.4 & 111.4 & $4.1 \pm 0.3$ & $1.0 \pm 0.3$ & 15.4 & 3.4 & $19.9 \pm 0.4$ & $34.4 \pm 0.4$ & 74.8 & 114.8 \\
\hline & River Sebangau & 150.0 & 445.8 & 460.8 & $17.3 \pm 0.4$ & $33.6 \pm 0.1$ & 667.9 & 1337.2 & $3.8 \pm 0.8$ & $1.5 \pm 0.1$ & 146.4 & 61.1 & $21.1 \pm 1.2$ & $35.1 \pm 0.2$ & 814.3 & 1398.3 \\
\hline & Total Mean & & 17.3 & 33.9 & 40.5 & 43.9 & 48.4 & 102.8 & 5.1 & 2.5 & 8.5 & 5.0 & 45.5 & 46.4 & 56.9 & 107.8 \\
\hline
\end{tabular}

\subsection{Dry season vs. wet season}

Average water discharge from the fourteen channels in the wet season $\left(34 \mathrm{~m}^{3} \mathrm{~s}^{-1}\right)$ was double that compared to in the dry season $\left(17 \mathrm{~m}^{3} \mathrm{~s}^{-1}\right)$, with the biggest interseasonal differences occurring in the upper reaches of the river (channels $1-7)$.

Over the course of the entire river, mean DOC concentration in the wet season $\left(46 \mathrm{mg} \mathrm{l}^{-1}\right)$ was slightly higher than in the dry season $\left(39 \mathrm{mg}^{-1}\right)$. Conversely, average POC concentrations were higher in the dry season $\left(5.2 \mathrm{mg} \mathrm{l}^{-1}\right)$ compared to the wet season $\left(2.7 \mathrm{mg}^{-1}\right)$. The fourteen channels display a similar trend; DOC concentration is higher in the wet season $\left(44 \mathrm{mgl}^{-1}\right)$ compared to the dry season(41 $\left.\mathrm{mg} \mathrm{l}^{-1}\right)$ and POC displays the reverse trend with higher concentrations in the dry season $\left(5 \mathrm{mg} \mathrm{l}^{-1}\right)$ compared to the wet season $\left(3 \mathrm{mgl}^{-1}\right)$.

\subsection{TOC export to the Java Sea}

In the dry season, the DOC and POC fluxes from the River Sebangau to the Java Sea were $0.00067 \mathrm{Tg} \mathrm{day}^{-1}$ and $0.00015 \mathrm{Tg} \mathrm{day}^{-1}$, respectively. In the wet season the DOC flux was double at $0.00134 \mathrm{Tg} \mathrm{day}^{-1}$ but the POC flux was less than half at $0.00006 \mathrm{Tg} \mathrm{day}^{-1}$. In order to convert these seasonal data into annual fluxes, Central Kalimantan average seasonal climate patterns were used which consist of three months (90 days) dry season and nine months (275 days) wet season (Hooijer et al., 2008). Using the 3:9 ("dry month: wet month") ratio, the annual TOC flux is estimated to be $0.46 \mathrm{Tg}$, with $93 \%(0.43 \mathrm{Tg})$ comprising DOC and $7 \%$ $(0.03 \mathrm{Tg})$ comprising POC. This estimate is restricted in its reliability as it is based on two sampling seasons over the course of a year. However, the strategic timing of our sampling campaigns should ensure our datasets are highly repre- sentative of both dry and wet seasons (Fig. 1). If there are any inorganic particulates present, the POC fraction may be a slight overestimate (see POC methods), however as this accounts for only $7 \%$ of the TOC, it would not alter the overall flux considerably.

Baum et al. (2007) estimate the River Siak's DOC flux into the ocean to be $0.3 \mathrm{Tg} \mathrm{yr}^{-1}$. This figure places the River Siak at number 17 on the ranking list of DOC exports of major global rivers (Ludwig et al., 1996). Baum et al. (2007) did not determine POC flux and therefore the TOC flux cannot be estimated. They also used dry and wet season data with an even balance between the two to work out mean monthly DOC fluxes due to slightly different climate patterns in Sumatra (the meridional migration of the Intertropical Convergence Zone). In Sumatra there is generally 6 months of dry season and 6 months of wet season (6:6 "dry month: wet month" ratio as opposed to 3:9 in Kalimantan). Using the respective climate ratios, the data imply that the River Sebangau discharges approximately $\sim 50 \%$ more DOC to the ocean per year than the River Siak.

\section{Discussion}

In our catchment scale study of fluvial organic carbon dynamics along the course of an Indonesian blackwater river, the observed trends can be explained through a combination of tributary inputs and in-stream processes.

\subsection{DOC}

In this fluvial carbon size fraction, the changes between 0$126 \mathrm{~km}$ from the source can be explained by simple mixing, with tributaries of different composition entering the river. For example, it is clear from figure 3 that in the wet season, 
tributary number 11 (Paduran II) is low in DOC and the discharge large enough in size $\left(41 \mathrm{~m}^{3} \mathrm{~s}^{-1}\right)$ to reduce the main channel DOC concentration post tributary discharge. An alternative, or additional, explanation for changes in DOC concentration is the result of in-stream processes such as microbial respiration and oxidation which results in DOC removal and appears to be a significant biotic mechanism in blackwater rivers (Meyer, 1986). Several studies have shown that in-stream production of DOC (for example from POC degradation) is small in comparison to that which is derived from terrestrial sources (e.g. Worrall et al., 2007).

The non-linear relationship observed (polynomial 2nd order; $r^{2}=0.99$ ) within a stretch of the river without major tributary inputs, suggests that some form of DOC removal is also taking place (Fig. 4b). Percent estuarine DOC removal at high tide (dry season) was estimated by extrapolating linear regressions between DOC and EC for samples collected at the lower end of the estuary, following the method of Spencer et al. (2007). This method permits an estimate of the DOC concentration of a freshwater end-member, assuming conservative mixing, with the difference between this estimate and the observed DOC concentration of the last freshwater sample $(\mathrm{EC}<200 \mu \mathrm{S})$ providing an indication of the amount of DOC removal that has occurred within the estuary. Linear regression lines were derived using the last three samples at the seaward end of the estuary $(150-144 \mathrm{~km})$ and for the last four samples (150-141 km). These suggested a removal of DOC in the Sebangau estuary of $27 \%$ and $12 \%$ respectively. It therefore appears that significant DOC processing is occurring in the estuary, reducing the flux into the ocean. This implies that the $\mathrm{C}$ flux measured from the river mouth, at least during the dry season high-tide sampling, is a smaller estimate when compared to the actual $\mathrm{C}$ loss from the peatland.

In the dry season, below $126 \mathrm{~km}$ from the source, the most likely DOC removal mechanism is via flocculation to become POC or adsorption to existing POC or mineral particles, resulting from decreased DOC solubility with increasing salinity (Battin et al., 2008). Studies of DOC transport through estuaries in temperate regions have shown varied evidence of conservative and non-conservative mixing in different systems (e.g. Spencer et al., 2007). In the tropical Siak estuary, Baum et al. (2007) reported a negative linear relationship $\left(r^{2}=0.97\right)$ between salinity and DOC concentration, suggesting conservative mixing during the period of observation.

\subsection{POC}

The movement of POC through river systems is very different to that of DOC. POC is subject to gravitational settling, hydrodynamic lift and drag forces which result in transport occurring as a series of discrete movements (Battin et al., 2008). This accounts for the larger in-stream variability and fluctuation of POC concentration down the river. The most likely cause for the overall decrease in POC concentration from source to mouth is gravitational settling onto the benthic layer of the river bed. River flow rates determine the proportion of the POC that is carried as suspended sediment within the water column and how much settles onto the river bed. When flow rates drop below a threshold value (variable depending on the river system), particulates accumulate on the river bed, while at flow rates above the critical value particulates are re-suspended and transported downstream (Wainwright et al., 1992). The source of the River Sebangau is $150 \mathrm{~km}$ inland, yet only $12 \mathrm{~m}$ a.s.l. Averaged over the entire course of the river, there is, therefore, only a $1 \mathrm{~m}$ change in elevation for every $12.5 \mathrm{~km}$ of river length. Such a low gradient leads to low water velocities throughout the river. The velocity at the source of the River Sebangau is considerably higher than at the mouth in both seasons, varying from $0.49 \mathrm{~m} \mathrm{~s}^{-1}$ to $0.57 \mathrm{~m} \mathrm{~s}^{-1}$ at the source and dropping to $0.12 \mathrm{~m} \mathrm{~s}^{-1}$ and $0.15 \mathrm{~m} \mathrm{~s}^{-1}$ at the river mouth during the dry and wet seasons respectively. It is likely, therefore, that higher flow rates in the upper reaches of the river suspend more particulates which result in higher POC concentrations being recorded. Similarly, lower flow rates towards the mouth of the river result in more benthic accumulation of POC and less POC in the water column. It may therefore be the case that there is no regular overall loss of POC from the river system, but instead a relocation of the suspended POC in the more turbulent upper reaches of the river to the river bed through deposition due to slower flowing water in the lower reaches of the river. If this is the case, then it is likely that there is episodic re-suspension of organic sediment during high flows which transport a pulse of POC into the ocean. This repositioning is possible, given the extensive interchange that occurs between the suspended and deposited POC fractions along the course of a river (Minshall et al., 1983).

Another explanation for decreasing POC concentrations along the course of the river is that there is a loss in total POC as a result of in-stream biological processes. Although very little research on invertebrate communities in PSF ecosystems has been conducted (Wells and Yule, 2008) and in particular, no biotic assessment of the River Sebangau has ever been carried out, it is known that blackwater rivers in Kalimantan contain a large number of fungal and bacterial communities, the former best suited to degrading particulates and the latter to consuming smaller molecules released during fungal metabolism (MacKinnon, 1996; Dudgeon, 2000). It is therefore possible that some form of biological POC degradation occurs, as is reported from temperate streams (Monaghan et al., 2001).

Finally, the large within-river variability seen across both seasons may be attributed to the influence of the fourteen channels that discharge into the River Sebangau. The positioning of these discharge points is represented in Fig. 5 by vertical lines, and the "inputs" denote the POC concentration of the channel prior to discharge into the River 
Sebangau. For example, in the dry season, River Paduran I (channel 9) is discharging water with a high POC concentration $\left(6.7 \mathrm{mg}^{-1}\right)$ relative to the River Sebangau. The effect of this POC input is seen in the next sample point immediately downstream. The influence of these inputs on the River Sebangau is also dependent upon the actual discharge rate (see Table 1). For example, in the wet season, a high POC concentration (relative to the River Sebangau) of $4.3 \mathrm{mg}^{-1}$ from the Pankoh channel (channel 10) has no influence on POC concentrations in the River Sebangau. This is because the discharge rate of this canal is so low that the overall POC flux (Table 1) is too small to have any effect on the concentration of the sample taken immediately downstream in the river.

\subsection{Dry season vs. wet season}

Most tropical regions only have two seasons; a wet season and a dry season with less rainfall, with the temperature staying relatively constant throughout the two seasons. This monsoonal climate is highly favourable for plant growth and results in large quantities of organic material being washed into rivers year round. As a result, we speculated that DOC concentrations should be relatively constant throughout the year, without evidence of the summer/autumnal peak that is commonly reported in temperate regions owing to maximum ecosystem productivity or autumn leaf fall (Wetzel and Manny, 1977; Naiman and Sibert, 1978; Skiba and Cresser, 1991). To some extent this is reflected in the similar DOC concentrations between seasons. However, the effect that an increased flow rate (frequently due to increased rainfall) has on DOC concentration is still unclear and can differ according to ecosystem type. In peatlands, which are typically permanently waterlogged, throughflow at both high and low water levels is through an organic layer which has been shown to result in a negative relationship between stream flow and DOC concentration due to the dilution effect (Clark et al., 2007; Schiff et al., 1998). The relationship in this study shows the opposite and may be attributed to the "flushing effect" whereby water with a high DOC concentration (due to long residence time in the soil/peat layer throughout the dry season) is washed into the rivers by the rising water level during the onset of the wet season (Pearce et al., 1986; Hornberger et al., 1994). A strong positive correlation between DOC concentration and discharge was also reported from the Congo basin which comprises evergreen forest, savannah and swamp forest (Coynel et al., 2005). The "flushing" process is enhanced when the previously dry or stagnant upper limits of the river bed/bank are inundated with large amounts of water as discharge rates increase (Casey and Farr, 1982). What effect seasonality has on POC concentrations is also uncertain. However it is clear that lower water tables during the dry season result in a larger area of peat drying out compared to during the wet season. It is this drying of the peat and the resulting increased rate of aerobic decomposition that destabilises the peat dome structure leading to denudation and increased amounts of POC being released during the dry season.

In summary, our data suggest that given its relatively small catchment size, the River Sebangau is a significant contributor of organic carbon to the ocean. DOC concentrations in the River Sebangau are amongst the highest ever recorded, exceeding most reported for other tropical rivers as well as all of the 'world rivers' mentioned by Ludwig et al. (1996). The Dumai River estuary in Sumatra (Indonesia) is the only other study to report such high concentrations of DOC ( $>60 \mathrm{mg} \mathrm{l}^{-1}$ ) that compare to those found in the River Sebangau (Alkhatib et al., 2007). However, due to its small size (discharge at river mouth of $16 \mathrm{~m}^{3} \mathrm{~s}^{-1}$ as opposed to $\sim 450 \mathrm{~m}^{3} \mathrm{~s}^{-1}$ from the River Sebangau), its estimated annual export of DOC $(0.03 \mathrm{Tg})$ is $\sim 15$ times smaller than from the River Sebangau. High DOC concentrations within the River Sebangau can be attributed to the large expanse of peatlands within the Sebangau catchment, thus supporting the general assumption that soil carbon is a major source of DOC in river waters (Hope et al., 1997; Aitkenhead and McDowell 2000; Alkhatib et al., 2007). High DOC concentrations may also be explained by anoxic conditions (present in waterlogged peatlands) which are known to constrain the activity of phenol oxidase, an enzyme which eliminates phenolic compounds in the presence of bimolecular oxygen (Freeman et al., 2001). Anoxic conditions therefore lead to higher concentrations of phenolic compounds, substantially reducing the biodegradation of organic matter which results in high concentrations of DOC. Soil carbon is also thought to be the main source of riverine POC (Hedges et al., 1986). POC concentrations are generally only a tenth of the DOC concentrations largely because of the low topography in the Sebangau catchment which results in slower runoff and a likely depositional environment throughout the river's course. Differences in DOC and POC concentrations do occur between dry and wet seasons, but the most pronounced interseasonal differences are between DOC and POC fluxes because these incorporate discharge which is strongly correlated with precipitation. TOC flux from the river to the ocean was nearly twice as large during the wet season, despite there being considerably higher POC concentrations in the dry season.

We estimate the TOC flux from the River Sebangau to the Java Sea to be $0.46 \mathrm{Tg} \mathrm{yr}^{-1}$, comprised of $93 \%(0.43 \mathrm{Tg})$ DOC and $7 \%(0.03 \mathrm{Tg})$ POC. This equates to a fluvial TOC flux per unit area over the whole catchment $\left(5200 \mathrm{~km}^{2}\right)$ of $88 \mathrm{~g} \mathrm{C} \mathrm{m}^{-2} \mathrm{yr}^{-1}$, a figure which far exceeds those reported for northern peatlands $\left(10-30 \mathrm{~g} \mathrm{C} \mathrm{m}^{-2} \mathrm{yr}^{-1}\right.$; Billet et al., 2010; Koehler et al., 2009; Nilsson et al., 2008). The entire land area of Indonesia is $\sim 1.9 \times 10^{6} \mathrm{~km}^{2}$ of which over $10 \%\left(206950 \mathrm{~km}^{2}\right)$ is covered by peat soils (Page et al., 2010). On extrapolating the Sebangau catchment DOC flux $\left(83 \mathrm{~g} \mathrm{C} \mathrm{m}^{-2} \mathrm{yr}^{-1}\right)$ to the total peat covered area of Indone-

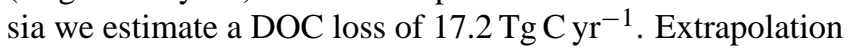
from one river basin to the entire peat covered land area of Indonesia has its limitations, which the authors duly note. 
These limitations, however, are somewhat reduced by the similarities between other river basins that have been studied in Indonesia (Alkhatib et al., 2007; Baum et al., 2007); most are made up of similar land use types (pristine/degraded peat swamp forest/agriculture) and the biogeochemistry of the draining rivers are highly comparable (DOC/POC concentration, $\mathrm{pH}$ ). Further confidence in our extrapolated result is that it approximates that of the Baum et al. (2007) estimate based on the River Siak ( $\sim 21 \mathrm{Tg} \mathrm{C} \mathrm{yr}^{-1}$ ) and in doing so provides some validation to the conclusion that Indonesian rivers account for approximately $10 \%$ of the global annual riverine DOC discharge into the ocean.

Acknowledgements. The authors are grateful to the Natural Environment Research Council for supporting SM via a CASE studentship (NE/F008813/1). This research was also co-funded by the Centre for Ecology and Hydrology (CEH). We would like to thank Suwido Limin, Kitso Kusin, Idrus Mohammed and all the staff and students from the University of Palangka Raya in Central Kalimantan for their assistance in the field as well as the boat crew for use of their vessel. We would also like to thank T. Jennerjahn, A. Coynel, F. Darchambeau, G. Anshari and two anonymous authors for their constructive criticisms which helped to improve the manuscript.

Edited by: S. Bouillon

\section{References}

Aitkenhead, J. A. and McDowell, W. H.: Soil C:N ratio as a predictor of annual riverine DOC flux at local and global scales, Global Biogeochem. Cy., 14, 127-138, 2000.

Alkhatib, M., Jennerjahn, T. C., and Samiaji, J.: Biogeochemistry of the Dumai River estuary, Sumatra, Indonesia, a tropical blackwater river, Limnol. Oceanogr., 52, 2410-2417, 2007.

Ballhorn, U., Siegert, F., Mason, M., and Limin, S.: Derivation of burn scar depths and estimation of carbon emissions with LIDAR in Indonesian peatlands, P. Natl. Acad. Sci. USA, 106, 2121321218, 2009.

Battin, T. J., Kaplan, L. A., Findlay., Hopkinson, C. S., Marti, E., Packman, A. I., Newbold, J. D., and Sabater, F.: Biophysical controls on organic carbon in fluvial networks, Nat. Geosci. 1, 95-100, 2008.

Battin, T. J., Luyssaert, S., Kaplan, L. A., Aufdenkampe, A. K., Richter, A., and Tranvik, L. J.: The boundless carbon cycle, Nat. Geosci., 2, 598-600, 2009.

Baum, A., Rixen, T., and Samiaji, J.: Relevance of peat draining rivers in central Sumatra for the riverine input of dissolved organic carbon into the ocean, Estuar. Coast. Shelf Sci., 73, 563570, 2007

Billet, M. F., Charman, D. J., Clark, J. M., Evans, C. D., Evans, M. J., Ostle, N. J., Worrall, F., Burden, A., Dinsmore, K. J., Jones, T., McNamara, N. P., Parry, L., Rowson, J. G., and Rose, R.: Carbon balance of UK peatlands: current state of knowledge and future research challenges, Clim. Res., 45, 13-29, 2010.
Casey, H. and Farr, I. S.: The influence of within-stream disturbance on dissolved nutrient levels during spates, Hydrobiologic, 92, 447-462, 1982.

Clark, J. M., Lane, S. N., Chapman, P. J., and Adamson, J. K.: Export of dissolved organic carbon from an upland peatland during storm events: Implications for flux estimates, J. Hydrol., 347, 438-447, 2007.

Coynel, A., Seyler, P., Etcheber, H., Meybeck, M., and Orange, D.: Spatial and seasonal dynamics of total suspended sediment and organic carbon species in the Congo River, Global Biogeochem. Cy., 19, GB4019, doi:10.1029/2004GB002335, 2005.

Degens, E. T., Kempe, S., and Richey, J. E.: Summary: Biogeochemistry of major world rivers, in: Biogeochemistry of major world rivers, SCOPE Rep. 32, edited by: Degens, E. T., Kempe, S., and Richey, J. E., John Wiley, New York, 1991.

Dudgeon, D.: The ecology of tropical Asian rivers and streams in relation to biodiversity conservation, Annu. Rev. Ecol. Syst., 31, 239-263, 2000.

Freeman, C., Evans, C. D., Monteith, D. T., Reynolds, B., and Fenner, N.: Export of organic carbon from peat soils, Nature, 412, 785, 2001

Haraguchi, A.: Effect of sulphuric acid discharge on river water chemistry in peat swamp forests in Central Kalimantan, Indonesia, Limnology, 8, 175-182, 2007.

Harrison, J., Caraco, N. F., and Seitzinger, S. P.: Global pattern and sources of dissolved organic matter export to the coastal zone: results from a spatially explicit, global model, Global Biogeochem. Cy., 19, GB4S04, doi:10.1029/2005GB002480, 2005.

Hedges, J. I., Clark, W. A., Quay, P. D., Richey, J. E., Devol, A. H., and Santos, U. d. M.: Composition and fluxes of particulate organic material in the Amazon River, Limnol. Oceanogr., 31, 717-738, 1986.

Hooijer, A., Van der Vat, M., Prinsen, G., Vernimmen, R., Brinkman, J. J., and Zijl, F.: Hydrology of the EMRP Area Water Management Implications for Peatlands, Technical Report Number 2 of the Master Plan for the Rehabilitation and Revitalisation of the Ex-Mega Rice Project Area in Central Kalimantan, Euroconsult Mott MacDonald and Deltares, Delft Hydraulics, 2008.

Hope, D., Billett, M. F., and Cresser, M. S.: A review of the export of carbon in river water: fluxes and processes, Environ. Pollut., 84, 301-324, 1994.

Hope, D., Billett, M. F., Milne, R., and Brown, T. A. V.: Exports of organic carbon in British rivers, Hydrol. Process., 11, 325-344, 1997.

Hornberger, G. M., Bencala, K. E., and Mcknight, D. M.: Hydrological controls on dissolved organic-carbon during snowmelt in the Snake River near Montezuma, Colorado, Biogeochemistry, 25, 147-165, 1994.

Koehler, A. K., Murphy, K., Kiely, G., and Scottocornola, M.: Seasonal variation of DOC concentration and annual loss of DOC from an Atlantic blanket bog in South Western Ireland, Biogeochemistry, 95, 231-242, 2009.

Ludwig, W., Probst, J. L., and Kempe, S.: Predicting the oceanic input of organic carbon by continental erosion, Global Biogeochem. Cy., 10, 23-41, 1996.

MacKinnon, K.: The Ecology of Kalimantan, 3rd volume, Oxford University Press, Oxford, 1996.

Meybeck, M.: Carbon, nitrogen and phosphorus transport by world 
rivers, American Journal of Science, 282, 401-450, 1982.

Meybeck, M.: Riverine transport of atmospheric carbon: Sources, global typology and budget, Water Air Soil Poll., 70, 443-463, 1993.

Meyer, J. L.: Dissolved organic carbon dynamics in two subtropical blackwater rivers, Archiv fuer Hydrobiologie, 108, 119-134, 1986.

Minshall, G. W., Petersen, R. C., Cummins, K. W., Bott, T. L., Sedell, J. R., Cushing, C. E., and Vannote, R. L.: Interbiome comparison of stream ecosystem dynamics, Ecol. Monogr., 53, $1-25,1983$.

Monaghan, M. T., Thomas, S. A., Minshall, G. W., Newbold, J. D., and Cushing, C. E.: The influence of filter-feeding benthic macroinvertebrates on the transport and deposition of particulate organic matter and diatoms in two streams, Limnol. Oceanogr., 46, 1091-1099, 2001.

Naiman, R. J. and Sibert, J. R.: Transport of nutrients and carbon from the Nanaimo River to its estuary, Limnol. Oceanogr., 23, 1183-1193, 1978.

Naiman, R. J., Melillio, J. M., Lock, M. A., Ford, T. E. and Rice, S. R.: Longitudinal patterns of ecosystem processes and community structure in a subartic river continuum, Ecology, 68, 11391156, 1987.

Nilsson, M., Sagerfors, J., Buffam, I., Laudon, H., Eriksson, T., Grelle, A., Klemedtsson, L., Weslien, P., and Lindroth, A.: Contemporary carbon accumulation in a boreal oligotrophic minerogenic mire - a significant sink after accounting for all C-fluxes, Global Change Biol., 14, 2317-2332, 2008.

Page, S. E., Rieley, J. O., Shotyk, O. W., and Weiss, D.: Interdependence of peat and vegetation in a tropical peat swamp forest, Philos. T. R. Soc. Lond., 354, 1885-1897, 1999.

Page, S. E., Siegert, F., Rieley, J. O., Boehm, H.-D. V., Jaya, A., and Limin, S.: The amount of carbon released from peat and forest fires in Indonesia during 1997, Nature, 420, 61-65, 2002.

Page, S. E., Wust, R. A. J., Weiss, D., Rieley, J. O., Shotyk, O. W., and Limin, S. H.: A record of late Pleistocene and Holocene carbon accumulation and climate change from an equatorial peat bog (Kalimantan, Indonesia): implications for past, present and future carbon dynamics, J. Quaternary Sci., 19, 625-635, 2004.

Page, S. E., Hoscilo, A., Wosten, H., Jauhiainen, J., Silvius, M., Rieley, J., Ritzema, H., Tansey, K., Graham, L., Vasander, H., and Limin, S.: Restoration ecology of lowland tropical peatlands in Southeast Asia - Current knowledge and future research directions, Ecosystems, 12, 888-905, 2009.

Page, S. E., Rieley, J. O., and Banks, C. J.: Global and regional importance of the tropical peatland carbon pool, Global Change Biol., 17, 798-818, 2010.
Pearce, A. J., Stewart, M. K., and Sklash, M. G.: Storm runoff in humid headwater catchments, Water Resour. Res., 22, 1263 1272, 1986.

Probst, J. L., Amiotte-Suchet, P., and Ludwig, W.: Continental erosion and river transports of carbon to oceans, in: Trends in Hydrology, edited by: Pandalai, S. G., Trivandrum, New Delhi, 1994.

Schiff, S., Aravena, R., Mewhinney, E., Elgood, R., Warner, B., Dillon, P., and Trumbore, S.: Precambrian shield wetlands: hydrologic control of the sources and export of dissolved organic matter, Clim. Change, 40, 167-188, 1998.

Skiba, U. and Cresser, M. S.: Seasonal changes in soil atmospheric $\mathrm{CO}_{2}$ concentrations in two upland catchments and associated changes in river water chemistry, Chem. Ecol., 5, 217-225, 1991.

Spencer, R. G. M., Ahad, J. M. E., Baker, A., Cowie, G. L., Ganeshram, R., Upstill-Goddard, R. C., and Uher, G.: The estuarine mixing behaviour of peatland derived dissolved organic carbon and its relationship to chromophoric dissolved organic matter in two North Sea estuaries (U.K.), Estuar. Coast. Shelf Sci., 74, 131-144, 2007.

Syvitski, J. P. M., Vörösmarty, C. J., Kettner, A. J., and Green, P.: Impact of humans on the flux of terrestrial sediment to the global coastal ocean, Science, 308, 76-380, 2005.

Thurman, E. M.: Developments in Biogeochemistry, in: Organic Geochemistry of Natural Waters, edited by: Nijhoff, M., Junk, Dordrecht, 1985.

UKHO: The United Kingdom Hydrographic Office (Online) (Date accessed: 23/03/2008) Available from the World Wide Web: http://www.ukho.gov.uk/Pages/Home.aspx The United Kingdom Hydrographic Office, 2008.

Wainwright, S. C., Couch, C. A., and Meyer, J. L.: Fluxes of bacterial and organic matter into a blackwater river from river sediments and floodplain soils, Freshwater Biol., 28, 37-48, 1992.

Wells, A. and Yule, C. M.: The caddisflies (Trichoptera) from a tropical peat swamp in Selangor, Peninsular Malaysia, including two new species, Aquat. Insect., 30, 69-76, 2008.

Wetzel, R. G. and Manny, B. A.: Seasonal changes in particulate and dissolved organic carbon and nitrogen in a hardwater stream, Archive Hydrobiology, 80, 20-39, 1977.

Worrall, F., Gulibert, T., and Besien, T.: The flux of carbon from rivers: the case for flux from England and Wales, Biogeochemistry, 86, 63-75, 2007.

Wösten, H. and Ritzema, H.: Subsidence and Water Management of Tropical Peatlands, Peatlands International, 2, 38-39, 2007. 